\title{
Educational Game Application Development on Classification of Diseases and Related Health Problems Treatment in Android Platform
}

\author{
Bernadus Rudy Sunindya \\ Department of Medical Record and Health Information \\ Malang State Health Polytechnics, Malang-Indonesia
}

\author{
Nur Hasti Purwani \\ Department of Medical Record and Health Information \\ Malang State Health Polytechnics, Malang-Indonesia
}

\begin{abstract}
The classification and codification of diseases and related problems is one of the competences of medical recorder as stated in Kepmenkes RI.377 in 2007. The current problem is the lack of reference exercise in learning KKPMT (Klasifikasi dan Kodifikasi Penyakit dan Masalah Terkait) in Program Diploma-III Medical Recorder and Health Information Malang State Health Polytechnics. The purpose of this research is to design android based KKPMT educational application to improve students understanding of KKPMT course. This investigation was using pre-experiment, one group pretestposttest with waterfall development method. The population in this study was all the students active in year two of Program Diploma-III Medical Record and Health Information Malang State Health Polytechnics. The result of the implementation showed that after the use of KKPMT educational game application with the diagnosis code $G$ the percentage was above minimum, passing value increased from $6 \%$ before using the game to $94 \%$ after implementation of the game application. Results of the statistical test by paired t-test showed p-value 0,000 $<0.05$. The conclusion was that android game software help students in understanding the KKPMT subject matter.
\end{abstract}

Keywords-Game; KKPMT (Klasifikasi dan Kodifikasi Penyakit dan Masalah Terkait); android

\section{INTRODUCTION}

Implementations of medical records need an important aspect in the success of health development that requires quality of human resources. Human resources in question are qualified professionals in the field of medical recorders and health information. In Kepmenkes RI No. 377 Year 2007 medical record education qualification consists of seven competencies that must be fulfilled as medical recorder [6]. One of the requirements in seven core competencies is the classification and codification of diseases, health and medical related issues. The medical coder should be able to assign codes and actions appropriately under International Classification of Disease $10^{\text {th }}$ Edition (ICD-10) and ICD 9Clinical Modification (ICD $9 \mathrm{CM}$ ). According to Gemala Hatta [5] in the book, Health Information Management Manual stated that WHO International Statistical Classification of Diseases and Related Health Problems (ICD) is a comprehensive classification system and recognized internationally. ICD-10 is published in three volumes. ICD-10 uses alphanumeric numbering code whereas ICD-9 is only numerical. ICD-10 Volume 3 is an alphabetical Index, a comprehensive list of all the conditions in the Tabulation (volume 1), external cause list, neoplasm table and guidance on selecting codes appropriate for various conditions not shown in the Tabular List [7]. The function of ICD as a disease classification system and related health problems is used for statistical purposes of morbidity and mortality.

In previous research, other researchers has developed an application in support of learning classification and codification of disease and problem (Klasifikasi Kodifikasi Penyakit dan Masalah Terkait/KKPMT) under the title "the use of information technology in classification learning and codification and related problems" by Nuryati [9]. The researcher develops learning aids on medical terminology and classification with the development of computer-based applications by methods e-learning. From the results obtained by the respondents, the e-learning application said to be helpful to improve the understanding in the course KKPMT. Also, shortcomings in the design of this system is the respondents had difficulty in running the e-learning applications.

According to Wahono [12], game is a structured or semistructured activity that usually aims for entertainment and sometimes used as a means of education. The characteristics of fun, motivating, addictive games and collaborative makes this activity popular with many people. Unwittingly the game can teach many skills, and games can serve as an alternative education [2].

From the results of a preliminary study with questionnaires conducted in Program Diploma-III Medical Record and Health Information Poltekkes Malang in December 2016 it was found that $76 \%$ of students are less enthusiastic and $76 \%$ of students want innovation in learning the subject of KKPMT. Students who are less eager to learn the subject matter KKPMT due to the less effective method of learning and lack of reference questions/exercises that support learning KKPMT. In addition to the problem of learning method, it was also found that the seven most challenging materials concerning certain conditions originating from the perinatal period; pregnancy, childbirth, and other item were in the group. Therefore, it is necessary to develop interactive learning method with suitable learning media and can be used by students to improve the understanding of subject-matter materials. One of the interesting learning media is the androidbased educational game that can be useful as an exercise. 
This research aims to develop educational game application design, classification and codification of diseases and related problems (KKPMT) based on android.

\section{METHOD}

The research design used in this study was using a type of pre-experimental research design using one group pre-test post-test. Research population is the whole object of research or object under study [8] and in this study, they are all active students; Level 2 in Malang State Health Polytechnics with the number of 78 students. The sample in this research is the all students of level 2 with a total number of 78 students. The sampling technique in this research is total sampling. The reason for taking the sample is because the amount of population is less than 100 so the whole population participated as the sample of the research [10].

\section{RESULTS}

Waterfall development and preliminary results of the study to the students of level 2 majors at Program Diploma-III Medical Record and Health Information Poltekkes Malang found that $76 \%$ of students are less enthusiastic and $76 \%$ of students want innovation in learning the subject of KKPMT. Researchers develop interactive and engaging learning methods with the establishment of educational games KKPMT.

\section{A. System Design}

\section{1) Process Specification}

Process specification is a description of each processing element contained in the program, which includes the process name, input, output, and description of the process. The specifications of the application process KKPMT educational game is shown in Table 1.

\section{2) Design Interface}

Design Interface is drawing a preliminary draft of the application to be built, to provide an overview of the application. It aims analyzing whether the position of the image or button is appropriate and can be recognized by the user.

Testing applications by using next stage black box testing: In the testing process conducted by making test cases that try all functions to ensure that gaming applications were in accordance the required specifications.

\section{3) Implementation of Educational Games}

KKPMT: After designing the subsequent application of researchers implemented in the form of pre-test and post-test, the pre-test proceeded on May 9, 2017 and post-test on May 10, 2017. Researchers apply educational game application KKPMT to sophomore class. Implementation was using pretest and post-test. The results of pre-test and post-test were written in the logbook sheets then processed to determine whether it meets the minimum passing grade.

Fig. 1 shows the code of the application which guides the game program. This code controls how the game application is used and it can be modified either for the expanded purposes.

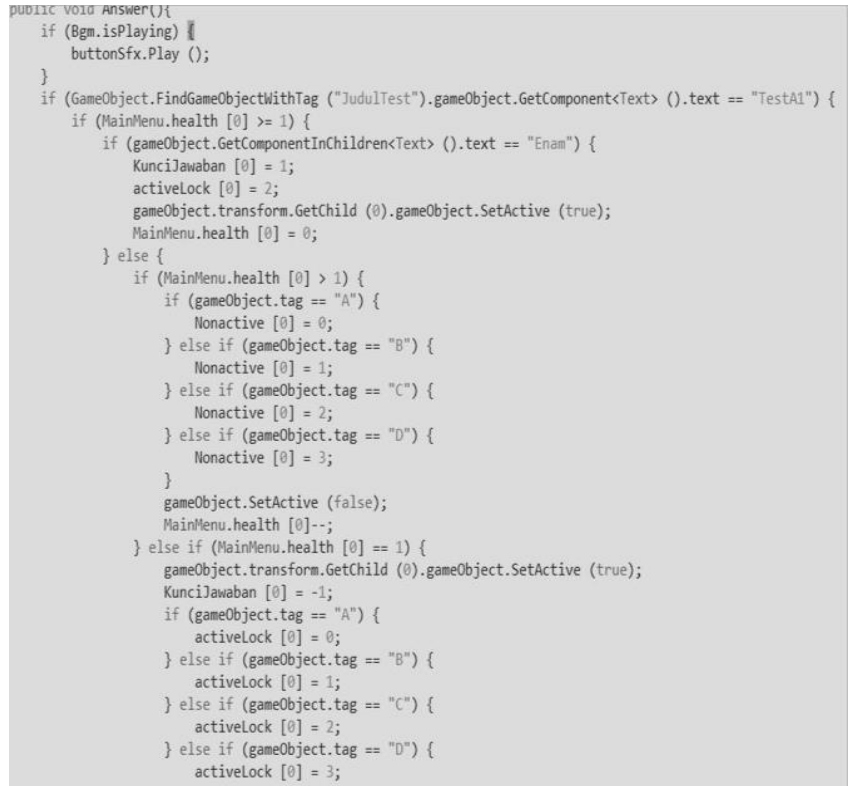

Fig. 1. Program code of the game application.

TABLE. I. RESUlts of PAIRED T-Test

\begin{tabular}{|l|l|l|l|}
\hline Situation & N & Average & P Value \\
\hline Before & 60 & 61 & 0.000 \\
\hline After & 60 & 75 & \\
\hline
\end{tabular}

Statistical analysis of some of the discussions that have been exposed by researchers, then the next step was to analyze the research data. Analysis of the research data was needed to determine whether there was the influence of educational game application usage towards 2nd level student in understanding the courses. All the statistical analysis were done using SPSS 24 for windows. The results are as follows:

In Table 1, it can be seen that the calculations using SPSS with paired T-test is obtained sig $=0.000$ sig. Smaller than $\alpha$ significance level value of 0.05 . This p-value implies that there was a difference of students' understanding mean of KKPMT materials about diseases between prior and after using educational and android game applications.

\section{DISCUSSION}

The waterfall model is a process model first proposed in 1970. This was named the waterfall because of the plot to flow from one stage to the next. Before designing the application there are phases in the form of preliminary study with questionnaires conducted to 79 students in December 2016. It showed that $76 \%$ of students were less enthusiastic and $76 \%$ of students want innovation in learning subjects KKPMT.

KKPMT educational game is a matter of the nervous system diseases, in the ICD-10 volume 1 code KKPMT G. Application educational game adapted from the WHO training can be accessed through the website http://apps.who.int/classifications/apps/icd/ICD10Training/ ICD10\% 20training/Starts /.

The increase of the average score of the students using the game application showed that with playing the game in android, the student gained cognitive ability and thus increased the score. This phenomenon provided evidence that 
learning with joyful environment makes longer retention of knowledge gain. However, it was unknown yet whether this learning tool can work as good as it was when the content upgraded to the next level of cognitive skills say analytical or even further up to synthesis.

User requirement consists of the user interface. This game was developed for casual learning, which gives the impression of a relaxed and pleasant. KKPMT educational game displays no time limit to complete each level so that the user gives the impression of a comfortable and fun to understand the material and answering questions. Users in this game are challenged to get a score or the highest score in the finish each game level. In designing Android-based educational game KKPMT, it required software and hardware support in the application process KKPMT educational game. The required software is a unity and test object program. The program used to create educational games KKPMT. Test object was an application to evaluate the game created. Design KKPMT educational game is a kind of education game with $2 \mathrm{D}$ graphics. According to Bates [1], a game must have elements that must be considered in making a game. The concept of learning through a quiz game is interesting. In the making of a game it also needed regulation. The rule in this educational game KKPMT user must complete the initial phase in order to open the next stage. KKPMT educational game displays no time limit to complete each level. Flow of KKPMT educational game journey begins on the user pay attention to codes of ICD-10 beginning then proceeds to answer the quizzes in each stage and at the end of the block there will be a review test. Review test contains a collection of all the matter from the beginning until the end of the stage. The process of this educational game scoring application if the user answered correctly will receive 1 point and if one of the score will be reduced by 1 point. Applications KKPMT educational game can be played by the students of medical recorder via android phone. Encoding Designs was then translated into the code to implement program logic. The program used is Unity. The programming language used was using java language. The programmer has the responsibility to test. Testing aims to find errors on the system and find the suitability of the system created with the needs of users. KKPMT educational game application testing was done using a black box testing. Black box testing was performed by an information system to get an average of $100 \%$. It can be concluded that the application of the game has already met the needs. According to Virvou [11], educational gaming technology can motivate learning and involve players, so the learning process is more fun. Educational games excel in some aspects when compared with conventional learning methods. One of the significant advantages is the animation that can improve memory so that it can store the subject matter for a longer time compared with conventional teaching methods [3]. According to Ghea [4], game is one part of learning with multimedia presentations; where the game presented refers to the learning process and with the multimedia program is expected to occur learning activities while playing. Thus users or users do not feel that they are actually learning.

Implementation of Educational Games KKPMT: Usage of KKPMT educational game application can be a tool to train on the code of the nervous system disease. KKPMT educational game application was played via android phone.

However, the result of this research was not interrelated with the academic achievement of the students since the content of the game was not arranged to the curriculum of the subject matter. Therefore in the future research, it is suggested to conduct similar research that included a full subject to the content of the game application so that the student's achievement in academic score can be measured and compared.

\section{CONCLUSIONS}

From the various explanations in this report, several things can be concluded as follows:

1) KKPMT-based educational game applications provides solutions to the problems faced in understanding the course KKPMT in particular diagnosis code $\mathrm{G}$ as well as a medium of learning solutions for students at Program Diploma-III Medical Record and Health Information Polytechnic of Malang.

2) The results of the implementation of pre-test and posttest are that the use of educational games app shows a percentage increase that gets above the minimum passing grade of $57 \%$.

3) Based on analysis of statistics on the table paired t-test it was found $\mathrm{p}$-value $0.000<0.05$ which means the game application did improved students' knowledge.

\section{REFERENCES}

[1] Bates, Bob. 2004. Game Design.Amerika: Thomson.

[2] Buckingham, D.A and Scanlon, F.G. 2006. The Effect of Violent Video Game Habits on Adolescent hostility, Aggressive Behaviours, and School Performance. Journal of Adolescence.

[3] Clark, Donald. 2006. Games and e-learning. Online: http://www.caspianlearning.- co.uk/Whtpcaspian-games_1.1.pdf. Diakses pada 28 November 2016.

[4] Ghea. 2012. Pengembangan Game Edukasi Pengenalan Nama Hewan Dalam Bahasa Inggris Sebagai Media Pembelajaran Siswa SD Berbasis Macromedia Flash (Skripsi). Yogyakarta: Universitas Negeri Yogyakarta.

[5] Hatta, Gemala. 2011. Pedoman Manajemen Informasi Kesehatan. Jakarta: Universitas Indonesia Press.

[6] Kementerian Kesehatan RI. 2007. Kepmenkes No. 337 Tahun 2007 tentang Standar Profesi Rekam Medis dan Informasi Kesehatan. Jakarta: RI.

[7] Kementerian Kesehatan RI. 2014. PMK No. 27 Tahun 2014 tentang Petunjuk Teknis Sistem Indonesian Case Base Groups. Jakarta: RI.

[8] Notoatmodjo, Soekidjo. 2012. Metodologi Penelitian Kesehatan. Jakarta : Rineka Cipta.

[9] Nuryati. 2013. Pemanfaatan Teknologi Informasi Dalam Pembelajaran Klasifikasi Dan Kodefikasi Penyakit Dan Masalah Terkait. Jurnal Manajemen Informasi Kesehatan Indonesia.

[10] Sugiyono. 2012. Metode Penelitian Kuantitatif Kualitatif dan R\&D. Bandung: Alfabeta.

[11] Virvou, Maria, et.al. 2005. Combining Software Games With Education: Evaluation of Its Educational Technology and Society. Educational Technology \& Society, 8 (2), 54-65.

[12] Wahono, Romi Satria. 2006. Aspek dan Kriteria Penilaian Media Pembelajaran.Online: http://romisatriawahono.net/2006/21/aspek-dankriteria-penilaian- 